\title{
Gedemilitariseerde sones: 'n Doeltreffende konflikbeslegtingsmetode?
}

\author{
deur Kapt. W.J.J. Coetzer*
}

\author{
It is assumed that demilitarized zones serve a useful purpose in physically dividing fighting \\ factions.
}

In this article the author advocates the point that in practice, demilitarized zones become nothing more than substitutes for final political solutions. He also maintains that demilitarized zones tend to worsen rather than defuse the conflict situation.

\section{Inleiding}

Die bestudering van grense en hul politieke en geografiese probleme is lank reeds vir politieke geograwe van belang. Grense baken die maksimum omvang van 'n staat se soewereiniteit af. Dit vorm verder die lyn van kontak tussen naburige state en is gewoonlik die fokuspunt vir probleme wanneer daar spanning tussen naburige lande heers.

Verskeie tipes grense het in die geskiedenis bestaan. Dit wissel van primitiewe grenssones tot die presiese liniêre grense van die moderne era. Die hoofneiging in die wêreldpolitiek was dan ook in die rigting van liniêre grense wat, in teenstelling met die vroeëre grenssones wat gebiede van skeiding tussen eenhede was, 'n lyn van skeiding tussen state vorm. 'n Belangrike 20steeeuse uitsondering tot die algemene gebruik van liniêre grense, is die gebruik van gedemilitariseerde sones as grense of as dele van grense (Salisbury, 1972: 109).

'n Gedemilitariseerde sone is 'n duidelik-omskrewe gebied waarin die stasionering van militêre magte en die handhawing en daarstelling van militêre installasies van enige aard, verbied word (Hayward (red), 1975: 54). Luttwak (1971: 69) stel dit dat slegs sekere militêre installasies verbied word. Die aard van die verbode installasies en reëlings vir veiligheidsmagte binne die sones (indien sodanige magte aangewend word), word in die ooreenkoms waarvolgens die gedemilitariseerde sones tot stand kom, bepaal.

Twee van die meer bekende gedemilitariseerde sones voor die tweede Wêreldoorlog was dié tussen Noorweë en Swede en dié in die Rynland in Duitsland. Sedert die Tweede Wêreldoorlog is vier sodanige sones geskep, te wete tussen Israel en Sirië (drie klein sones), in Korea, in Viëtnam en tussen El Salvador en Honduras (Salisbury, 1972: 109-110).

\section{Doel/Bestek}

Gedemilitariseerde sones word in hierdie geskrif bespreek en geëvalueer. Die redes vir die skepping van gedemilitariseerde sones word opgevolg met ' $n$ kort beskrywing van die verskillende tipes gedemilitariseerde sones. Hierna word die blik op gedemilitariseerde sones in die praktyk gewerp. Die Israeli-Siriese, Viëtnamese en Koreaanse gedemilitariseerde sones word bespreek. Verder word die voorgestelde gedemilitariseerde sone tussen SWA/Namibië en Angola bespreek. Die geskrif word afgesluit met ' $n$ bespreking van die redes wat tot die mislukking van gedemilitariseerde sones aanleiding gegee het.

\section{Redes vir die skepping van gedemilitariseerde sones}

Die antwoord op die vraag waarom gedemilitariseerde sones as plaasvervanger vir tradisionele formele, liniêre grense gebruik word, lê in die veranderde aard van wapenstilstandooreenkomste in die 20ste eeu.

Die meeste moderne grense is die resultaat van komplekse gebeurtenisse wat uiteindelik deur ' $n$ politieke verdrag geformaliseer is. Die gebeure wat tot ' $n$ politieke definisie en afbakening van ' $n$ grens lei, varieer van direkte onderhandeling tot gewapende konflik. Die kritieke element is dat daar ' $n$ politieke konferensie waaraan die betrokke partye deelneem, gehou word, en uiteindelik 'n polities-geskepte en -bekragtigde grens tot stand gebring word. Dit impliseer natuurlik nie dat die grens nie betwis en geskend word nie, maar eerder dat dit polities bekragtig en op ' $n$ politieke oplossing gebaseer is (Salisbury, 1972: 110).

'n Wapenstilstandooreenkoms impliseer normaalweg ' $n$ tydelike staking van vyandighede en 


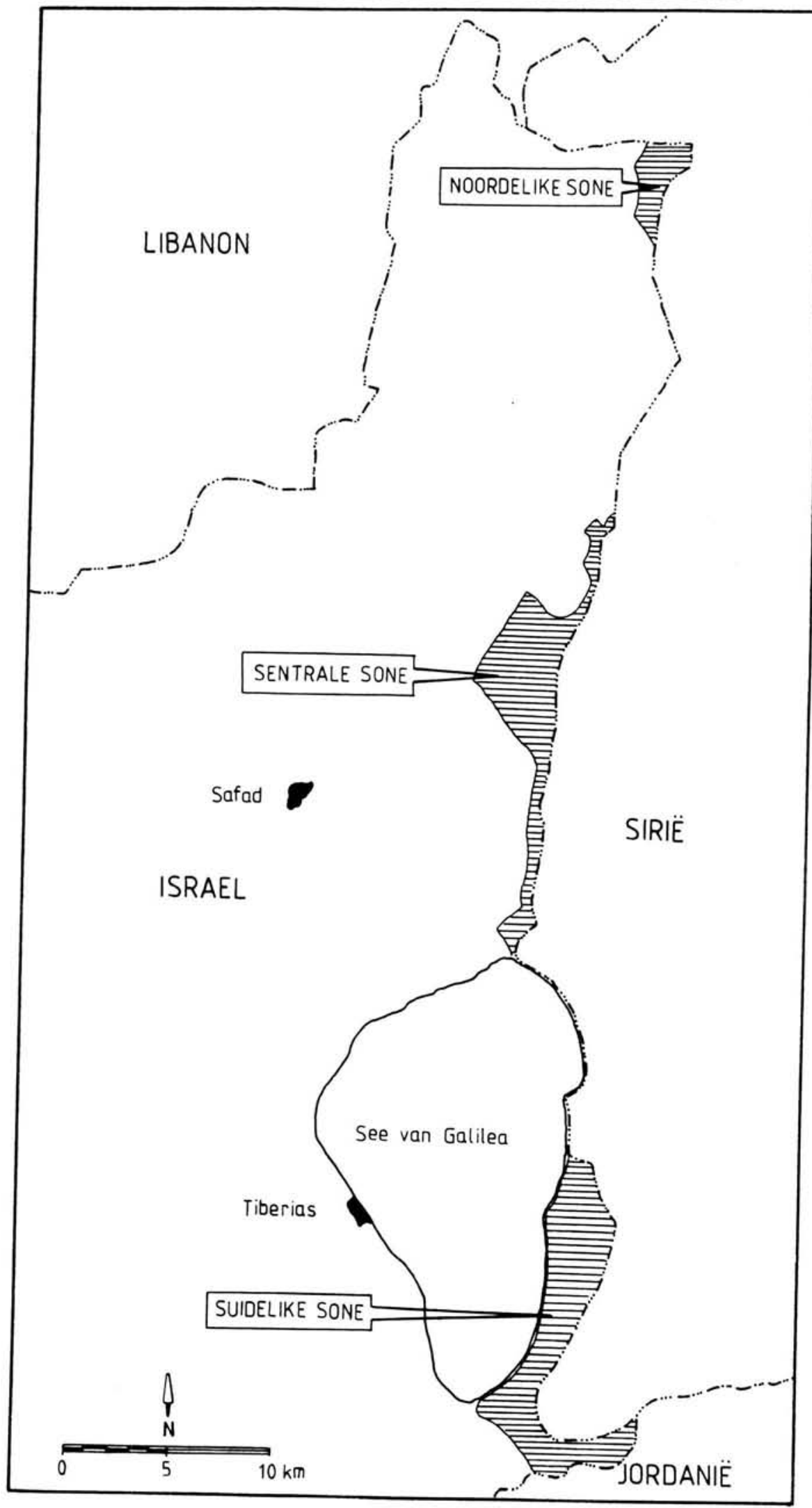

(Haupert, 1969: 164)

Israell-Siriese gedemilitariseerde sone 
dit word aangegaan om gevegte te staak totdat ' $n$ vredesverdrag, wat die oorlog finaal beëindig, onderteken is. In die 20ste eeu was daar egter nie minder nie as elf gevalle waar ' $n$ wapenstilstandooreenkoms nie deur ' $n$ vredesverdrag opgevolg is nie. Dit lei noodwendig tot die intensifisering van vyandighede en magsopbou tydens die duur van die wapenstilstand.

Weens die onduidelikheid met betrekking tot die wetlike status van besette grondgebiede, het dit gebruik geword om een of ander tipe gedemilitariseerde sone in wapenstilstandooreenkomste te vervat. Dit word veronderstel dat sodanige sones 'n nuttige doel dien om die strydende partye fisies van mekaar te skei totdat ' $n$ vredesverdrag gesluit word. Aangesien vredesverdrae of politieke oplossings in soveel gevalle van wapenstilstande nie bereik is nie, het gedemilitariseerde sones en wapenstilstande die de factooplossing vir sodanige konflikte geword (Salisbury, 1972: 110).

\section{Tipes gedemilitariseerde sones}

Hough (1980: 94) onderskei vier tipes gedemilitariseerde sones. Die eerste tipe is 'n bewoonde gebied waarvan die sowereiniteit betwis word. Die tweede tipe is onbewoon, maar 'n gebied van strategiese belang. Derdens is daar sones wat beide onbewoon en nie-strategies is, sogenaamde "niemandslande". Die vierde tipe gedemilitariseerde sone, gewoonlik onbewoon, word uitsluitlik vir die plasing van 'n vredesmag geskep. Die terme "buffersone" en "cordon sanitaire" word soms (verkeerdelik) vir gedemilitariseerde sones gebruik, maar dit verwys inderwaarheid na die eensydige afseëling van ' $n$ grens deur middel van byvoorbeeld 'n mynveld of elektriese heining.

\section{Gedemilitariseerde sones in die praktyk}

Israeli-Siriese gedemilitariseerde sones. Dié sone is geskep om 'n territoriale geskil tussen Israel en Sirië te besleg. Die dispuut dateer na die Arabies-Israeli Oorlog van 1948 terug. Israel se onafhanklikheidsverklaring in dié jaar het tot gevolg gehad dat ses Arabiese lande, te wete Egipte, Transjordanië (Jordanië), Sirië, Libanon, Irak en Saoedi-Arabië vir Israel binnegeval het. Israel kon die aanslag op al die fronte, behalwe in die ou deel van Jerusalem en drie klein gebiede langs die Siriese grens, afweer. $\mathrm{Na}$ die aangaan van ' $n$ wapenstilstand het Sirië steeds dié drie gebiede beset en hulle was onwillig om dit te ontset. Israel het geweier om die Siriërs in die gebiede te aanvaar, aangesien Israel dit as hul soewereine gebied beskou het (Salisbury, 1972: 111-2).

Die Verenigde Volke Organisasie (VVO) het die leiding geneem om bogenoemde konflikgebiede in gedemilitariseerde sones te omskep. Aangesien die VVO die konflik as ' $n$ ernstige bedreiging vir wêreldvrede beskou het, het hulle die siening gehandhaaf dat 'n snelle skikking noodsaaklik was. Druk is op Sirië uitgeoefen en die Israeli-Siriese Wapenstilstandskommissie (Gemengde Wapenstilstandskommissie) is vroeg in 1949 gestig. In Julie 1949 is hul voorstel vir die demilitarisering van die konflikgebiede (kyk figuur 1) deur beide Israel en Sirië aanvaar en 'n wapenstilstandooreenkoms is gesluit. Volgens die ooreenkoms sou alle troepe uit die sones onttrek word en geen militêre toerusting en fortifikasies toegelaat word nie. Die sones sou deur 'n mag, wat uit plaaslike inwoners saamgestel is, beveilig word en toegang tot die sone sou deur die voorsitter van die Gemengde Wapenstilstandkommissie ('n VVO-verteenwoordiger) beheer word. Alle onopgeloste probleme sou deur die voorsitter van die Kommissie hanteer word (Salisbury, 1972: 112-3). Hierdie voorstelle is deur beide Israel en Sirië aanvaar.

Die presiese politieke status van die gedemilitariseerde sones was egter nie in die ooreenkoms gestipuleer nie en Israel en Sirië het verskillende interpretasies aan die presiese betekenis van die woord "gedemilitariseerde sone" gekoppel. Israel se interpretasie was dat hulle, behalwe vir militêre beperkinge, totale soewereiniteit in die sones gehad het (Hauper, 1969: 167). Sirië het dit as internasionale sones onder VVO gesag beskou, en die siening gehuldig dat beide partye gelyke regte in die sones gehad het. ' $n$ Gevolg van hierdie verwarring was dat beide lande angstig was om soveel beheer moontlik in die sones te verkry.

Soos wat dit baie keer die geval met onopgeloste konflik is, het Israel en Sirië hulle tot militêre mag gewend om die stryd te besleg. Grensskendings en skermutselinge het gereeld plaasgevind en in omvang en intensiteit toegeneem. Teen die einde van 1966 het die situasie breekpunt bereik en vroeg in 1967 het die Gemengde Wapenstilstandkommissie (vir die eerste keer sedert 1960) vergader in 'n poging om die konflik te besleg. Geen ooreenkoms kon bereik word nie en in Junie 1967 het die "Sesdaagse 


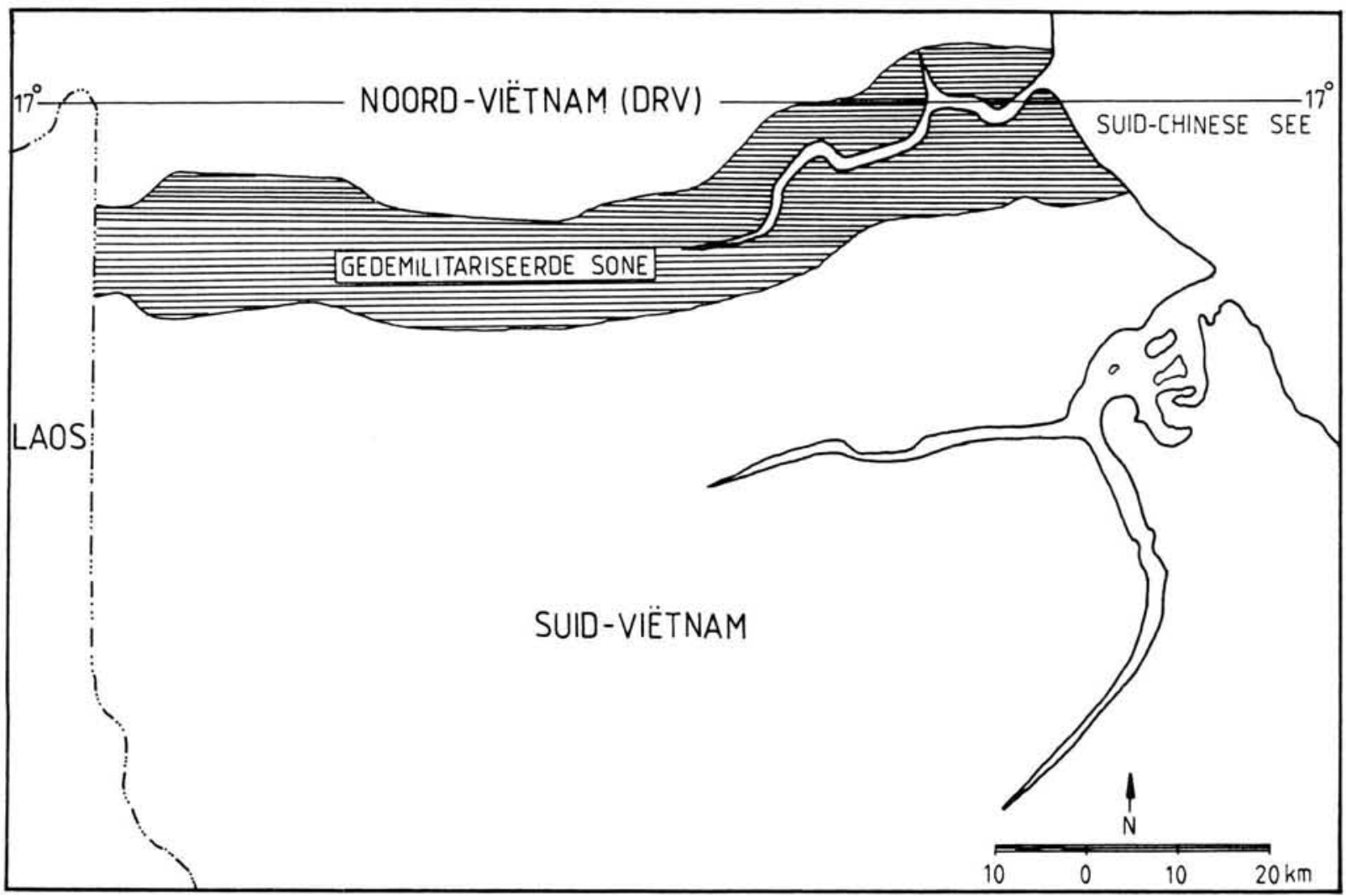

(Nalty 1979:57)

\section{Viëtnamese gedemilitariseerde sone}

Oorlog" plaasgevind. Israel se sukses in hierdie oorlog het verseker dat dié land die betwiste gebiede beset het en daarmee het die gedemilitariseerde sones verval (Salisbury, 1972: 116).

Die Viëtnamese gedemilitariseerde sone. Die verdeling van Viëtnam kan in 'n groot mate aan Franse en Japannese heerskappy oor dié land toegeskryf word. Reeds in 1885 was die hele Viëtnam onder Franse beheer en gedurende die Tweede Wêreldoorlog het Japan dele van Viëtnam beset. Alhoewel die Viëtnamese hulle vroeg reeds teen die Franse heerskappy verset het, is die tydperk tussen die twee wêreldoorloë deur die opkoms van 'n sterk Viëtnamese nasionalisme gekenmerk. Die "Liga vir die Onafhanklikheid van Viëtnam" (Viëtminh) het daarin geslaag om die Japannese Viëtnam te verslaan en in 1945 is die Demokratiese Republiek Viëtnam (DRV) deur hulle uitgeroep (Abraham, 1983: 149).

Tydens die Potsdam-konferensie in 1945 is daar besluit dat die gebiede wat Japan beset het, onder Chinese en Britse beheer verdeel sou word. Die 16de breedtegraad sou die skeidslyn wees en die DRV sou sy gesag in die noordelike deel (Noord-Viëtnam) handhaaf. In die Britse sone is die terugkeer van die Franse bevorder. Frankryk het nie die bestaansreg van die DRV ontken nie en het beloof dat 'n referendum oor die posisie van die besette Suide gehou sou word. Later het die Franse egter militêre posisies in die Noorde ingeneem en die aandrang van die Viëtminh dat die hele Viëtnam as ' $n$ eenheid erken moet word, het op dowe ore geval. Spanning het toegeneem, die Franse militêre posisie het verswak en met die Viëtminh se verowering van die vesting Dien Bien Phu op 7 Mei 1954, het dit duidelik geword dat die Franse 'n nederlaag gelei het (Abraham, 1983: 149).

Daar is reeds vroeër, in Februarie 1954, ooreengekom dat 'n konferensie in Genève belê sou word om die moontlikheid van vrede in Viëtnam te bespreek. Op 8 Mei het die samesprekings ' $n$ aanvang geneem en die Sowjet-Unie, Frankryk, Die Verenigde Koninkryk, die VSA, China, Laos, Kambodja en die regerings van Noord- en Suid- 
Viëtnam het daaraan deelgeneem. In Julie dieselfde jaar is die Ooreenkoms rakende die Beëindiging van Vyandighede in Viëtnam deur verteenwoordigers van Frankryk en Noord-Viëtnam onderteken. Die Finale Deklarasie, waarin die hoofpunte van die Ooreenkoms vervat is, is mondeling deur Frankryk, Noord-Viëtnam, die Sowjet-Unie, die Verenigde Koninkryk en China aanvaar. Die VSA en Suid-Viëtnam het dit nie aanvaar nie (Haviland, Fabian, Mathiasen \& Cox, 1968, 6-7).

Die belangrikste bepalings van die Ooreenkoms was soos volg:

(a) Daar moes ' $n$ totale en gelyktydige staking van vyandelikhede in die hele Viëtnam wees en ' $n$ terugtrekking van magte tot hul betrokke kante van 'n voorlopige skeidslyn op ongeveer die 17 de breedtelyn.

(b) Geen troepe, versterkings, addisionele militêre personeel, wapens, ammunisie of krygstuig mag in die gedemilitariseerde sone van $10 \mathrm{~km}$ breed (kyk figuur 2) gevestig word nie.

(c) Geen nuwe basisse mag in die gedemilitariseerde sone gevestig word nie.

(d) 'n Internasionale Kommissie, bestaande uit verteenwoordigers van Indië, Kanada en Pole, is in Viëtnam gevestig om die sone te beheer en die Ooreenkoms af te dwing $(\mathrm{Ha}-$ viland, et al, 1968: 7-8).

Soos in die geval van Israel, het die gedemilitariseerde sone nie tot vrede tussen die betrokke partye gelei nie. Alhoewel die sone as ' $n$ buffer tussen die vyandelike magte bestaan het, is dit grootliks deur Noord-Viëtnam geïgnoreer en het die Internasionale Kommissie geen sukses in die afdwinging van die Genève-bepalings behaal nie (Nöthling, 1982: 5). Die Viëtminh-guerillas het via Laos asook deur die gedemilitariseerde sone na Suid-Viëtnam geïnfiltreer en die oorlog het, met toenemende Amerikaanse betrokkenheid, geëskaleer (Nalty, 1979: 60-1). Met die onttrekking van die Amerikaanse magte uit SuidViëtnam in 1975, het die gedemilitariseerde sone in die niet verdwyn en Suid-Viëtnam was binne weke in die hande van die Noord-Viëtnamese magte (Nöthling, 1982: 6).

Die Koreaanse gedemilitariseerde sone. Japan het Korea vanaf $1910-1945$ as 'n kolonie regeer. Nadat die Japannese in 1945 deur Rusland en die VSA in Korea verslaan is, is die land langs die 38ste breedtelyn verdeel. Dié lyn was as ' $n$ tydelike maatreël ingestel, maar die op- koms van die Koue Oorlog het daartoe gelei dat dit tot 'n vaste front tussen die twee Koreaanse state ontwikkel het. Twee vyandige regerings is weerskante van die lyn ingestel. Noord-Korea is deur die Sowjet-Unie en Suid-Korea deur die VSA gesteun.

Bogenoemde lyn het met Noord-Korea se verrassingsaanval op die Suide in 1950, verval. 'n Jaar later het Amerikaanse divisies daarin geslaag om die kommunistiese magte tot noord van die 28 ste breedtelyn terug te dryf en 'n nuwe verdedigingslyn tot stand te bring. Hierdie lyn het, anders as die vorige een, langs dominerende terrein en verskeie waterhindernisse gestrek. Dié lyn het die basis gevorm vir die verdelingslyn en gedemilitariseerde sone wat na die Koreaanse Wapenstilstand van 1953 ingestel is (kyk figuur 3). Dié sone het van wes na oos, met ' $n$ breedte van vier kilometer, gestrek en dit vorm vandag nog die formele skeidslyn tussen Noorden Suid-Korea (Rees, 1976: 1, 3).

Soos met die vorige gevallestudies, het hierdie gedemilitariseerde sone nie vrede gebring nie, maar eerder die spanning verhoog. NoordKorea maak steeds aanspraak op die suidelike gebied en daarom het die land met 'n grootskaalse magsopbou direk noord van die gedemilitariseerde sone begin. Sedert laat 1974 het die Noord-Koreane meer as 800 versterkte artillerievestings langs die sone gebou en sommige kanonne het die vermoë om Seoel, Suid-Korea se hoofstad, te tref. Verder is verskeie FROG-7 grond-tot-grond missiele, wat Seoel kan tref, in versterkte vestings geïnstalleer, verskeie lughawens is binne drie tot vier minute se vliegtyd vanaf Seoel gebou en nuwe vlootbasisse is ook gebou. Die leër wat permanent noord van die gedemilitariseerde sone ontplooi is, is met twee pantserdivisies versterk (Rees, 1976: 2-3).

Dié magsopbou het eers werklike betekenis verkry toe daar in 1974 ' $n$ tonnel van drie kilometer lank onder die gedemilitariseerde sone deur die Amerikaners ontdek is. Dié tonnel was vier voet hoog, vier voet wyd en die dak en mure was van beton gebou. Behalwe vir elektriese beligting was daar ' $n$ smal spoorlyn met die vermoë om 'n regiment troepe met uitrusting, binne die bestek van een uur, onderdeur die gedemilitariseerde sone te vervoer. Dié ontdekking het tot ' $n$ volskaalse soektog na verdere tonnels gelei en in Maart 1975 is ' $n$ tweede tonnel ontdek. Hierdie tonnel, as 'n "underground highway" beskryf, was twee keer so groot soos die vorige, ses voet by ses voet en vyf kilometer lank. Dit was groot 


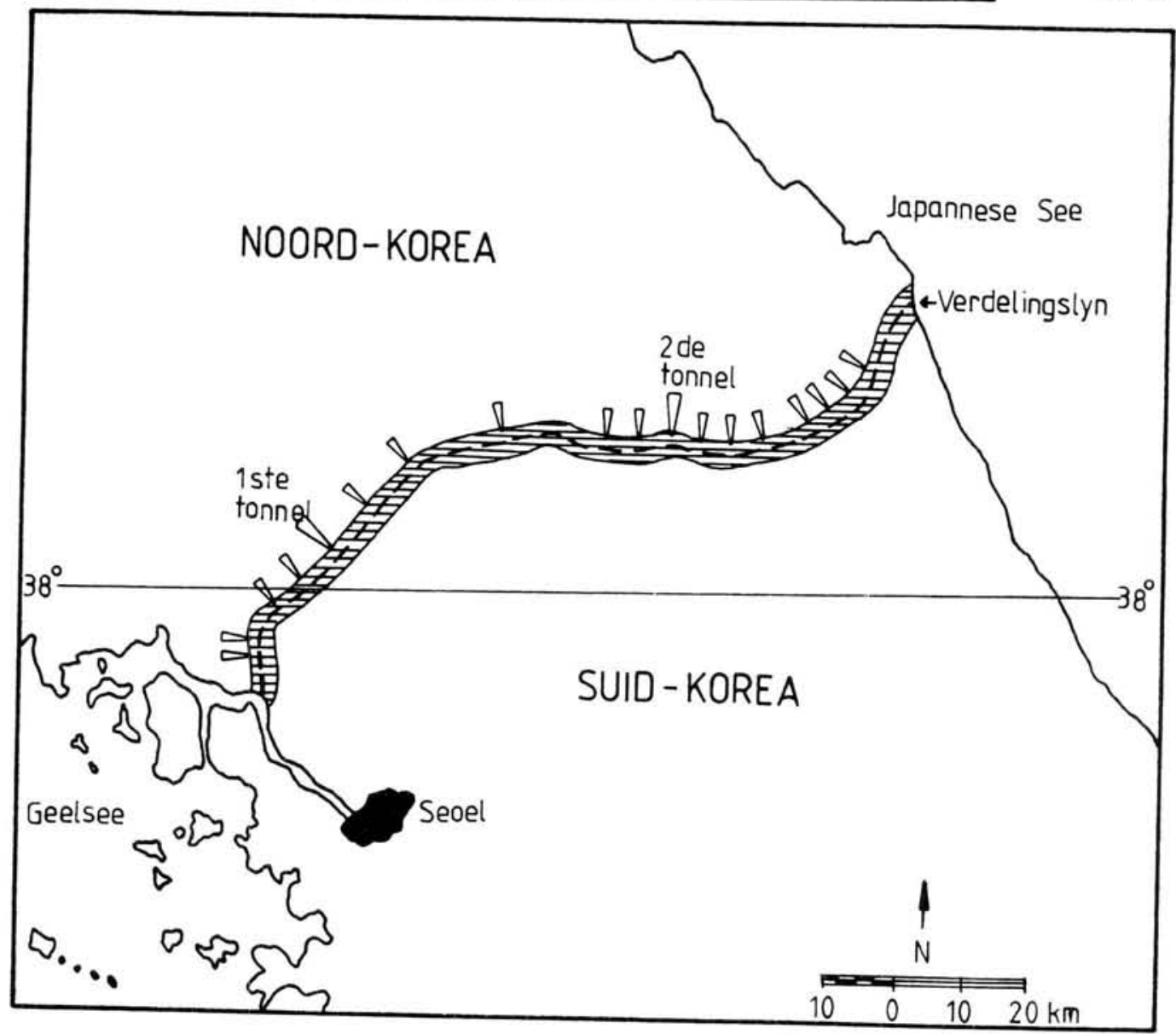

(Rees, 1976:7 ; Godfrey, 1981:60)

\section{Koreaanse gedemilitariseerde sone}

Alhoewel die idee van ' $n$ gedemilitariseerde sone in beginsel deur beide die RSA en Swapo aanvaar is, is die detailbepalings rakende die sone deur beide partye verwerp. Suid-Afrika se verwerping was primêr op die volgende gegrond:

(a) Die onpartydigheid van die VVO is bevraagteken.

(b) Die VVO wou nie die interne politieke partye in SWA/Namibië erken nie.

(c) Unita het nie aan enige samesprekings rakende die implementering van die gedemilitariseerde sone, deelgeneem nie.

(d) Die VVO se bevestiging dat Swapo as die enigste wettige verteenwoordiger van die bevolking van SWA/Namibië beskou word en dat met geen politieke party behalwe Swapo, onderhandel sal word nie (Du Pisanie, 1981: 26; Hough, 1980: 92-3).
Samesprekings rakende die gedemilitariseerde sone het gedurende 1980 en 1981 voortgeduur, maar geen ooreenkoms kon tussen die RSA en Swapo bereik word nie. Sedertdien is die implementering van die gedemilitariseerde sone as moontlike oplossing vir die SWA/Namibië kwessie op die agtergrond geskuif en dit is hoogs twyfelagtig of so ' $n$ sone ooit ' $n$ realiteit sal word. genoeg vir klein voertuie en artilleriestukke om daardeur te beweeg en volgens berekening kon twee divisies binne een uur via die tonnel na Suid-Korea verplaas word (Rees, 1976: 3-4). Tot in 1976 is ' $n$ totaal van agtien tonnels ontdek (kyk figuur 3).

Hierdie tonnels was 'n verbreking van die Wapenstilstandooreenkoms van 1953 en die ontdekking daarvan het tot hernude spanning tussen Noord- en Suid-Korea gelei. Nogtans is die gedemilitariseerde sone tussen Noord- en 
Suid-Korea die langsbestaande sodanige sone in die geskiedenis. Die moontlikheid van toekomstige konflik tussen die twee Koreas kan egter nie uitgesluit word nie.

Voorgestelde gedemilitariseerde sone tussen SWA/Namibië en Angola. Die idee van 'n gedemilitariseerde sone tussen bogenoemde twee lande is in 1979 deur dr. Neto, voormalige President van Angola, voorgestel. Vir hom was dit ' $n$ heraktivering van samesprekings betreffende SWA/Namibië se onafhanklikheid nadat die RSA die wapenstilstandvoorstelle van Februarie 1979 verwerp het (Anon, 1980(a): 555).

Detail vir die daarstelling van 'n gedemilitariseerde sone is deur die Westerse Kontakgroep (verteenwoordigers van Brittanje, Kanada, Frankryk, Wes-Duitsland en die VSA) opgestel. Die sone sou die geweldige oppervlakte van $140000 \mathrm{~km}^{2}$ dek, 1400 kilometer lank en 100 kilometer breed wees. Vyftig kilometer binne SWA/Namibië en Angola asook dele van suidwestelike Zambië en die hele Caprivi-strook sou ingesluit wees, maar die sone sou nie tot binne Botswana strek nie (sien figuur 4) (Anon, 1980(b): 17).

\section{Redes vir die gebrek aan effektiwiteit}

Die gebrek aan effektiwiteit van gedemilitariseerde sones is ' $n$ belangrike politieke probleem van die moderne tyd. Vir Salisbury (1972: 109) is gedemilitariseerde sones geopolitieke uitdruk-

\section{SWA/NAMIBIË-ANGOLESE GEDEMILITARISEERDE SONE FIG 4}

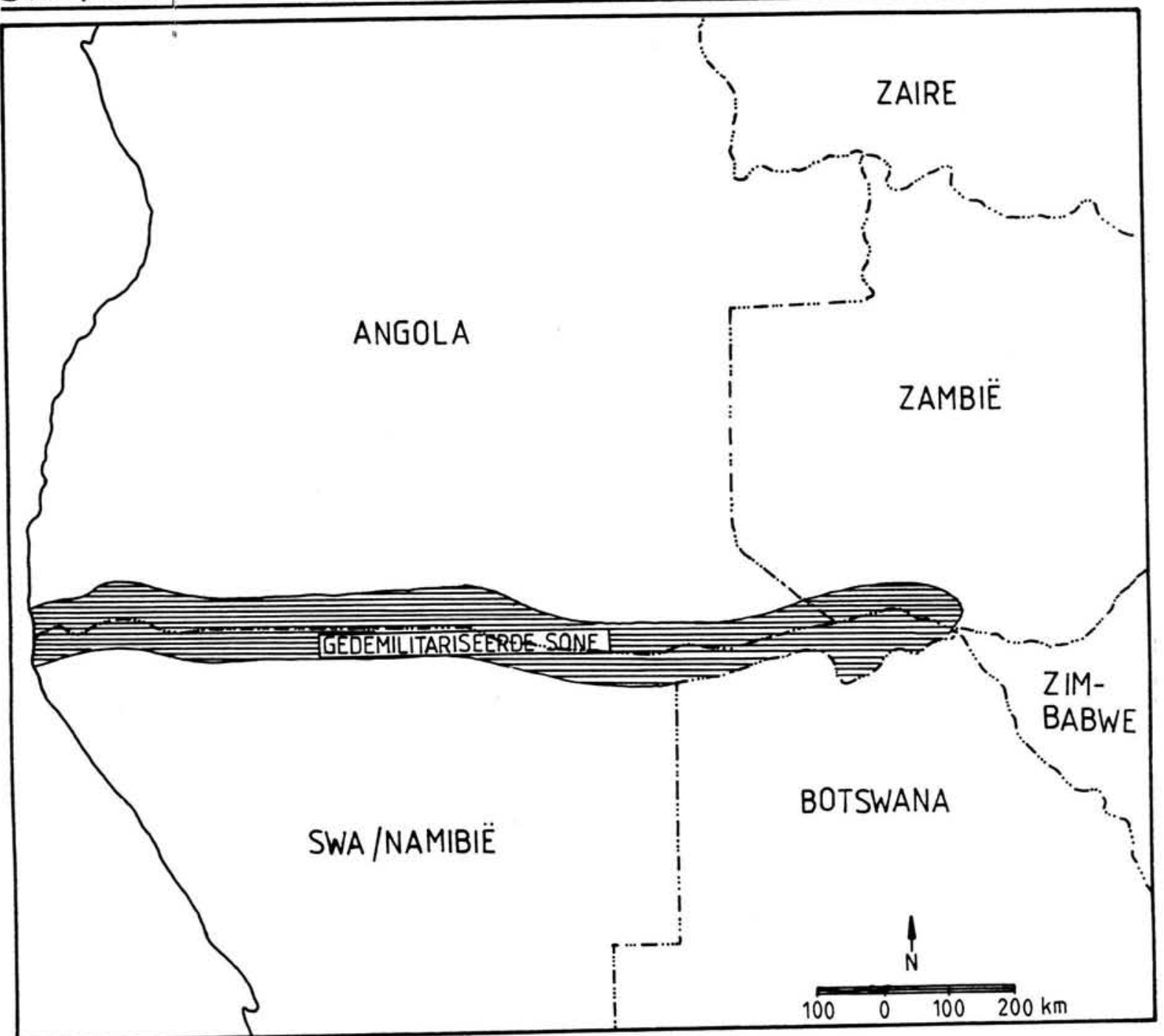

(Hough, 1980: 92) 
kings van onopgeloste konflik. Dié sones het plaasvervangers vir finale politieke oplossings geword en as sodanig neig dit om baie onstabiel te wees en om konflik te vererger, eerder as om dit te ontlont. Die volgende knelpunte met betrekking tot die effektiwiteit van gedemilitariseerde sones word geïdentifiseer:

(a) Toesighouding, inspeksie en bevestiging. Die belangrikste knelpunt is dié van toesighouding, inspeksie en bevestiging van die. demilitarisasiebepalings. Hierdie aspek is een van die moeilikste punte van ooreenstemming tussen die betrokke partye en is belangrik genoeg om 'n skikking te verhoed. Verder kan 'n gedemilitariseerde sone se sukses selfs ná die ondertekening van 'n ooreenkoms deur konsensus betreffende die bevestiging van demilitarisasiebepalings, bepaal word.

(b) Toesighoudings-, inspeksie, en bevestigingsmetodes kan die volgende insluit: observasieposte, elektroniese uitrusting, lugverkenning of ' $n$ toesighoudingsmag. Laasgenoemde kan deur die VVO, buitemoondhede of die betrokke partye self onderneem word. (Peleg, 1984: 267-9). Die oneffektiwiteit en partydigheid van toesighoudingsmagte was in die verlede een van die hoofredes waarom gedemilitariseerde sones misluk het (sien para 14, 18 en 27).

(c) Formulering van demilitarisasie-ooreenkomste. Die presiese politieke status van 'n gedemilitariseerde sone moet in die betrokke ooreenkoms gestipuleer word en daar moet verseker word dat die betrokke partye eenstemmigheid oor die presiese betekenis en implikasies van die term "gedemilitariseerde sone" het. Dit het, soos reeds vermeld, tot die mislukking van die gedemilitariseerde sone tussen Israel en Sirië gelei.

(d) Skending van demilitarisasie-ooreenkomste. Dit is van essensiële belang dat die betrokke partye eerlik in hul optredes moet wees en die demilitarisasie-bepalings moet nakom. Geen gedemilitariseerde sone kan suksesvol wees as enige van die betrokke partye oneerlik is of op 'n bedekte wyse optree nie. Die sones in Korea en Viëtnam dien as uitstekende voorbeelde waar ooreenkomste geskenk is. Volgens Peleg (1984: 261, 270) moet skendings openlik in die demilitarisasie-ooreenkoms afgekeur word, en moet die nakoming van die betrokke bepalings wetlik afdwingbaar wees.

(e) Omseiling van demilitarisasie-bepalings. 'n Gedemilitariseerde sone kan nie sukses- vol wees wanneer die bepalings omseil word deur magsopbou in die onmiddellike omgewing daarvan nie. Noord-Korea se omvangryke magsopbou direk noord van die gedemilitariseerde sone (kyk para 22) dien as voorbeeld. Hierdie knelpunt is veral van belang waar offensiewe wapens die vermoë het om bo-oor ' $n$ gedemilitariseerde sone te vuur.

(f) Funksionaliteit en permanentheid van die gedemilitariseerde sone. Demilitarisasievoorwaardes moet funksioneel wees in dié sin dat dit die sekuriteit van die betrokke partye en die stabiliteit van die politieke ooreenkoms moet bevorder (Peleg, 1984: 265). Finale en permanente bepalings betreffende die gedemilitariseerde sone met in die betrokke ooreenkoms of verdrag vervat word (Peleg, 1984: 264). Dit sal verhoed dat die sone as 'n tydelike maatreël, waartydens herorganisasie en magsopbou kan plaasvind, beskou word.

\section{Gevolgtrekking}

Dit word veronderstel dat ' $n$ gedemilitariseerde sone ' $n$ nuttige doel dien om strydende partye fisies van mekaar te skei. In die praktyk het gedemilitariseerde sones egter niks anders as tydelike plaasvervangers vir finale politieke oplossings geword nie. Dit neig verder om konflik te vererger, eerder as om dit te ontlont.

Die primêre rede vir die mislukking van gedemilitariseerde sones lê in die probleme wat met toesighouding, inspeksie en bevestiging van demilitarisasie-bepalings, ondervind word. Ander belangrike redes vir mislukking is die vaagheid van demilitarisasie-ooreenkomste en die skending en omseiling van demilitarisasie-bepalings. Voordat hierdie probleme nie uit die weg geruim word nie, sal geen gedemilitariseerde sone aan die doel waarvoor dit ingestel wod, voldoen nie.

* Kapt W.J.J. Coetzer, SA InI K, het in Desember 1982 die B Mil-graad aan die Universiteit van Stellenbosch verwerf, met hoofvakke Staatsleer en Militêre Geografie. Hy is tans ' $n$ honneursstudent in Militêre Geografie aan die Militêre Akademie en beklee terselfdertyd die adjudantspos by genoemde eenheid.

\section{Bronne}

Anon, 1980 (a). South West Africa. New UN initiative. Africa Research Bulletin. Vol 17, № 1. January 1980

Anon, 1980 (b). DMZ plan: Swapo under pressure. New African. January 1980.

Abraham, J.E. 1983. Viëtnam. In Wêreldspektrum. Pretoria: Ensiklopedie Afrikana (Edms) Bpk.

Du Pisani, A. 1981. SWA/Namibië: 1980 review. Africa Insight. Vol 11, No 1. 1981. 
Godtrey, F.A. 1981. Crisis in Korea. In Brown, A. \& S. Elder (reds). 1981 War in Peace. London: Orbis Publishing Limited.

Haupert, J.S. 1969. Political geography of the Israeli-Syrian boundary dispute, 1949-1967. The Professional Geographer. Vol 21, No 3. May 1969

Haviland, H.F., L.L. Fabian, K. Mathiasen \& A.M. Cox. 1968. Viëtnam after the war: peacekeeping and rehabilitation. Washington: The Brookings Institution.

Hayward, P.H.C. (red). Jane's dictionary of military terms. London: Macdonald and Jane's.

Hough, M. 1980. DMZ proposals for SWA/Namibië. Africa Insight. Vol 10, No 2. 1980.

Luttwak, E. 1971. A dictionary of modern war. London: The Penguin Press.
Nalty, B.C. 1979. Rival ideologies in a divided nation. In Bonds, R. 1979. The Viëtnam War. London: Salamander Books Ltd.

Nöthling, C.J. 1982. Die doeltreffendheid van gedemilitariseerde sones in Cyprus, Viëtnam, Kongo, Lebanon, ens. Ongepubliseerde geskrif van HSI, Pretoria.

Peleg, I. 1984. Solutions for the Palestinian question: Israeli's security dilemma. Comparative Strategy. Vol 4, № 3. 1984.

Rees, D. 1976. North-Korea: Undermining the Trucer. Conflict Studies. No 69. March 1976.

Salisbury, H.G. 1972. The Israeli-Syrian Demilitarized zone: An examination of unresolved conflict. The Journal of Geography. Vol 71. February 1972. 